\title{
UPAYA MENINGKATKAN KEMAMPUAN DIRI KLIEN HALUSINASI MELALUI TERAPI AKTIVITAS KELOMPOK DI YAYASAN MENTARI HATI KOTA TASIKMALAYA
}

\section{EFFORTS TO IMPROVE SELF-ABILITY IN HALLUCINATING CLIENTS THROUGH GROUP ACTIVITY THERAPY AT THE MENTARI HATI FOUNDATION, TASIKMALAYA CITY}

\author{
Peni Cahyati*, Ridwan Kustiawan, Dudi Hartono \\ Politeknik Kesehatan Kota Tasikmalaya, Jalan Cilolohan No. 35 Tasikmalaya \\ Email: peni_poltekestsm@yahoo.com \\ (Diterima 30-08-2021; Disetujui 15-09-2021)
}

\begin{abstract}
ABSTRAK
Gejala yang muncul pada skizofrenia terdiri atas gejala positif dan gejala negatif. Gejala negatif adalah afek tumpul/datar, menarik diri. Sedangkan gejala-gejala positif yang diperlihatkan oleh penderita skizofrenia seperti delusi (waham), kekacauan alam pikir, gaduh gelisah, dan halusinasi. Prinsip tindakan keperawatan pada klien halusinasi adalah membina hubungan saling percaya, memvalidasi persepsi, menghadirkan realita, menurunkan kecemasan, melindungi klien/orang lain dari bahaya halusinasi, dan meningkatkan peran serta keluarga dalam merawat klien halusinasi. Tindakan yang dapat dilakukan antara lain: terapi individual, terapi biologis, terapi kognitif, terapi lingkungan, terapi bermain, terapi keluarga, terapi perilaku, dan terapi kelompok. Terapi Aktifitas Kelompok sebagai bagian dari terapi modalitas dalam praktek keperawatan jiwa memberikan dampak yang positif dalam upaya pencegahan, pengobatan atau terapi dan pemulihan kesehatan jiwa seseorang. Terapi Aktifitas Kelompok Stimulasi Sensori merupakan aktifitas yang digunakan untuk memberikan stimulasi pada sensori klien. Yayasan Mentari Hati merupakan salah satu yayasan yang menampung pasien dengan gangguan jiwa yang tidak ada keluarganya Untuk membantu pasien halusinasi kami mengadakan pengabdian masyarakat dengan melaksanakan Terapi Aktifitas Kelompok di Yayasan Mentari Hati Kota Tasikmalaya Jumlah respoden sebanyak 36 orang dibagi menjadi 4 kelompok, dari hasil observasi didapatkan seluruh pasien meningkat kemampuan dirinya dalam mengenal halusinasi, menghardik,kepatuhan minum obat, bercakap-cakap, dan membuat jadwal kegiatan.
\end{abstract}

Kata kunci : Skizofrenia, halusinasi, terapi aktifitas kelompok

\begin{abstract}
Symptoms that appear in schizophrenia consist of positive symptoms and negative symptoms. Negative symptoms are blunted/flat affect, withdrawn. While the positive symptoms shown by people with schizophrenia such as delusions (delusions), chaos of thought, noise, anxiety, and hallucinations. The principle of nursing action on hallucinating clients is to build a trusting relationship, validate perceptions, present reality, reduce anxiety, protect clients/others from the dangers of hallucinations, and increase family participation in treating hallucinatory clients. Actions that can be taken include: individual therapy, biological therapy, cognitive therapy, environmental therapy, play therapy, family therapy, behavioral therapy, and group therapy. Group therapy activity as part of modality therapy in mental nursing practice has a positive impact in efforts to prevent, treat or treat and restore one's mental health. NO Sensory Stimulation is an activity that is used to provide sensory stimulation to the client. The Mentari Hati Foundation is one of the foundations that accommodates patients with mental disorders who have no family. To help patients with hallucinations, we hold community service by implementing Group Activity Therapy at the Mentari Hati Foundation, Tasikmalaya City. The number of respondents was 36 people divided into 4 groups, based on observations. It was found that all patients improved their ability to recognize hallucinations, rebuke, obediently take medication, converse and schedule activities.
\end{abstract}

Keywords: Schizophrenia, hallucinations, group therapy activity 
Upaya Meningkatkan Kemampuan Diri Klien Halusinasi Melalui Terapi Aktivitas Kelompok di Yayasan Mentari Hati

\section{PENDAHULUAN}

Skizofrenia adalah sekelompok reaksi psikotik yang memengaruhi berbagai area fungsi individu, termasuk berfikir dan berkomunikasi, menerima dan menginterpretasikan realitas, merasakan dan menunjukan emosi, dan berperilaku dengan sikap yang dapat diterima secara sosial (Ann, 2004). Studi epidemiologi menyebutkan bahwa perkiraan angka prevalensi skizofrenia secara umum berkisar antara $0,2 \%$ hingga 2,0\% tergantung di daerah atau negara mana studi tersebut dilakukan. Di Indonesia sendiri angka penderita skizofrenia diperkirakan 1 sampai 3 per 1.000 penduduk (Hawari, 2009). Menurut Azrul Azwar (Dirjen Bina Kesehatan Masyarakat Depkes), angka itu menunjukan jumlah penderita gangguan kesehatan jiwa di masyarakat yang sangat tinggi, yaitu satu dari empat penduduk Indonesia menderita kelainan jiwa mulai dari rasa cemas, depresi, stres, penyalahgunaan obat, kenakalan remaja sampai skizofrenia

Gejala yang muncul pada skizofrenia terdiri atas gejala positif dan gejala negatif (Hawari, 2009). Gejala negatif adalah afek tumpul/datar, menarik diri. Sedangkan gejalagejala positif yang diperlihatkan oleh penderita skizofrenia seperti delusi (waham), kekacauan alam pikir, gaduh gelisah, dan halusinasi. Halusinasi adalah suatu keadaan dimana seseorang mengalami perubahan dalam jumlah dan pola dari stimulus yang mendekati (yang diprakarsai secara internal dan eksternal) disertai dengan suatu pengurangan, berlebih-lebihan, distorsi atau kelainan berespon (Townsend, 2005). Prinsip tindakan keperawatan pada klien halusinasi adalah membina hubungan saling percaya, memvalidasi persepsi, menghadirkan realita, menurunkan kecemasan, melindungi klien/orang lain dari bahaya halusinasi, dan meningkatkan peran serta keluarga dalam merawat klien halusinasi.

Tujuan tindakan keperawatan pada klien halusinasi adalah membantu klien mengenal halusinasi yang dialaminya, mengontrol halusinasi, dan mengikuti program pengobatan secara optimal. Tindakan yang dapat dilakukan antara lain: terapi individual, terapi biologis, terapi kognitif, terapi lingkungan, terapi bermain, terapi keluarga, terapi perilaku, dan terapi kelompok. Terapi Aktifitas Kelompok (TAK) merupakan bagian dari terapi modalitas dalam praktek keperawatan jiwa memberikan dampak yang positif dalam upaya pencegahan, pengobatan atau terapi dan pemulihan kesehatan jiwa seseorang. Terapi aktifitas kelompok sering dipergunakan dalam praktik keperawatan jiwa, bahkan dewasa ini terapi aktifitas kelompok merupakan bagian yang penting dari keterampilan terapeutik dalam keperawatan. 
Beberapa keuntungan yang dapat diperoleh oleh individu atau klien melalui terapi aktifitas kelompok: dukungan, pendidikan, meningkatkan kemampuan pemecahan masalah, meningkatkan hubungan interpersonal, meningkatkan uji realitas pada klien gangguan orientasi realitas (Keliat et al., 2011). TAK telah diterima oleh profesi kesehatan, administrator dan masyarakat sebagai metode yang efektif dan efisien untuk menyelesaikan masalah pada klien gangguan jiwa. Aktifitas digunakan sebagai terapi, dan kelompok digunakan sebagai target asuhan. Di dalam kelompok terjadi dinamika interaksi yang saling bergantung, saling membutuhkan, dan menjadi laboratorium tempat klien berlatih perilaku baru yang adaptif untuk memperbaiki perilaku lama yang maladaptif (Suharsimi, 2006). Tindakan keperawatan yang ditujukan pada sistem klien, baik secara individu, keluarga, kelompok, dan masyarakat merupakan upaya yang menyeluruh dalam menyelesaikan masalah klien. Dengan evaluasi dan penelitian tentang manfaat TAK yang akan memberikan kontribusi terhadap perkembangan terapi kelompok dalam keperawatan jiwa.

Semua kemampuan yang dipelajari klien dalam TAK hendaknya digunakan sampai klien pulang ke rumah. TAK Stimulasi Sensori merupakan aktifitas yang digunakan untuk memberikan stimulasi pada sensori klien. Kemudian diobservasi reaksi sensori klien berupa ekspresi emosi atau perasaan melalui gerakan tubuh, ekspresi muka, ucapan. Biasanya klien yang tidak mau mengungkapkan komunikasi verbal akan terstimulasi emosi dan perasaannya, serta menampilkan respon melalui aktivitas tertentu. Aktivitas yang digunakan sebagai stimulus dapat berupa: musik, seni, menyanyi, menari. Jika hobi klien diketahui sebelumnya, misalnya nyanyian kesukaan klien dapat digunakan sebagai stimulus.

TAK Stimulasi Persepsi/Kognitif yaitu klien dilatih mempersepsikan stimulus yang disediakan atau stimulus yang pernah dialami. Kemampuan persepsi klien dievaluasi dan ditingkatkan pada setiap sesi. Yayasan Mentari Hati merupakan salah satu yayasan yang menampung pasien dengan gangguan jiwa yang tidak ada keluarganya. Pasiennya berjumlah 200 orang, sementara yang merawat sejumlah 10 orang. Di yayasaan tersebut hanya menampung serta memenuhi kebutuhan dasar manusia saja, namun kegiatan yang terkait dengan cara perawatan menurut kesehatan belum dilakukan. Dari uraian di atas, maka sebagai wujud rasa tanggung jawab terhadap peningkatan derajat kesehatan masyarakat dan sebagai bentuk pengamalan tri dharma perguruan tinggi, kami mengadakan suatu kegiatan pengabdian masyarakat di Yayasan Mentari Hati Kota Tasikmalaya. 
Upaya Meningkatkan Kemampuan Diri Klien Halusinasi Melalui Terapi Aktivitas Kelompok di Yayasan Mentari Hati

\section{BAHAN DAN METODE}

Pengabdian Masyarakat dilakukan di Yayasan Mentari Hati Kota Tasikmalaya dengan jumlah responden 36 orang klien dengan masalah halusinasi. Pelaksanaan pengabdian ini dimulai dengan melakukan perijinan ke Ketua Yayasan Mentari Hati Kota Tasikmalaya. Pada saat pelaksanaan di bagi menjadi 4 kelompok, setiap kelompok terdiri atas 9 orang klien. Setting kegiatan di atur duduk secara melingkar, setiap pasien didampingi oleh fasilitaor yaitu mahasiswa keperawatan. Kegiatan Terapi aktifitas kelompok dipimpin oleh leader dan co leader, serta di observasi jalannya kegiatan oleh observer. Setelah 45 menit kegiatan selesai observer melaporkan hasil observasi nya berupa tingkat kemampuan dari klien pada setiap sesi yang dilaksanakan yaitu sesi 1 : mengenal halusinasi, sesi 2: Menghardik, sesi 3: Kepatuhan minum obat, sesi 4: Bercakapcakap dan sesi 5: Membuat jadwal kegiatan.

\section{HASIL DAN PEMBAHASAN}

Hasil penilaian tingkat kemampuan klien halusinasi pada kegiatan TAK dapat dilihat pada Tabel 1.

\begin{tabular}{|c|c|c|c|c|c|}
\hline No & Sesi & Sebelum TAK & $\mathrm{f}$ & Sesudah TAK & $\mathrm{f}$ \\
\hline 1 & Mengenal halusinasi & 0 & 0 & 25 & 69,4 \\
\hline 2 & Menghardik & 0 & 0 & 25 & 69.4 \\
\hline 3 & Kepatuhan minum obat & 0 & 0 & 22 & 61,1 \\
\hline 4 & Bercakap-cakap & 0 & 0 & 21 & 58,3 \\
\hline 5 & Membuat jadwal kegiatan & 0 & 0 & 19 & 52,7 \\
\hline
\end{tabular}

Dari hasil observasi di atas menunjukkan bahwa klien sebelum dilakukan terapi aktifitas kelompok semuanya tidak memliki kemampuan, hal tersebut disebabkan karena klien yang berada di Yayasan Mentari Hati Tasikmalaya merupakan klien yang berada di jalanan sehingga belum tersentuh oleh tenaga Kesehatan/tenaga keperawatan. Setelah dilakukan TAK ada peningkatan di setiap sesi. Sesi paling besar yaitu mengenal dan menghardik sebanyak $69,4 \%$, dan terkecil pada sesi membuat jadwal kegiatan sebanyak $52,7 \%$. Hal ini sesuai dengan beberapa penelitian yang telah dilakukan mengenai TAK diantaranya menurut Talilah (2011) yang menunjukan adanya pengaruh TAK stimulasi persepsi terhadap kemampuan mengontrol halusinasi. Demikian pula penelitian (Suryaningsih et al., 2007) yang menunjukan bahwa TAK stimulasi persepsi berpengaruh terhadap penurunan frekuensi halusinasi.

Kesamaan hasil penelitian ini dengan hasil penelitian sebelumnya berimplikasi bahwa terapi aktivitas kelompok stimulasi persepsi dapat dijadikan alternatif pilihan terapi 
untuk penanganan klien dengan halusinasi.. Hal ini didukung dengan teori yang menyatakan TAK stimulasi persepsi halusinasi bertujuan untuk membentuk kemampuan klien untuk menyelesaikan masalah dengan stimulus yang diberikan kepada pasien

TAK sebagai bagian dari terapi modalitas dalam praktek keperawatan jiwa memberikan dampak yang positif dalam upaya pencegahan, pengobatan atau terapi dan pemulihan kesehatan jiwa seseorang. TAK sering dipergunakan dalam praktik keperawatan jiwa, bahkan dewasa ini TAK merupakan bagian yang penting dari keterampilan terapeutik dalam keperawatan (Herawati, 1999). Beberapa keuntungan yang dapat diperoleh oleh individu atau klien melalui terapi aktifitas kelompok: dukungan, pendidikan, meningkatkan kemampuan pemecahan masalah, meningkatkan hubungan interpersonal, meningkatkan uji realitas pada klien gangguan orientasi realitas (Birck head, 1989).

Tahap persiapan yang dilakukan oleh perawat atau kelompok terapis yang terdiri atas leader, co-leader, fasilitator serta observer dalam pembagian tugas yang jelas sangat penting untuk dipersiapkan, sehingga apa yang direncanakan sesuai dengan target atau tujuan yang diharapkan. Hal ini sesuai dengan teori dari (Gail Wiscarz Stuart, 2013) bahwa hal penting yang harus diperhatikan pada saat memulai kelompok adalah tujuan dari kelompok. Ketercapaian tujuan sangat dipengaruhi oleh perilaku pemimpin kelompok. Langkah persiapan yang perlu dilakukan oleh kelompok terapis adalah: menentukan tujuan umum dan khusus, daftar kelompok disertai keahliannya, kerangka teoritis yang akan digunakan, kriteria anggota kelompok, proses seleksi, serta uraian struktur kelompok (Gail Wiscarz Stuart, 2013).

Orientasi ini perlu dilakukan agar peserta TAK dapat memahami dan mengerti selama proses TAK berlangsung sehingga terbentuk kohesifitas antar peserta. Pada tahap orientasi hendaknya pemimpin kelompok atau leader lebih aktif dalam memberi pengarahan, mengorientasikan anggota pada tugas utama, melakukan kontrak (topik, waktu dan tempat), tujuan, kerahasiaan, kejujuran dan aturan komunikasi, misalnya hanya satu orang yang boleh bicara pada satu waktu, norma, perilaku, rasa memiliki, atau kohesif antara anggota kelimpok diupayakan terbentuk pada fase orientasi (Gail W Stuart \& Sundeen, 2012).

\section{KESIMPULAN DAN SARAN}

Ada peningkatan kemampuan klien dengan halusinasi, sebelum dan sesudah dilakukan Terapi Aktifitas Kelompok. 
Upaya Meningkatkan Kemampuan Diri Klien Halusinasi Melalui Terapi Aktivitas Kelompok di Yayasan Mentari Hati

\section{DAFTAR PUSTAKA}

Ann, I. (2004). Panduan Belajar Keperawatan Kesehatan Jiwa dan Psikiatri (D. P. Rahayuningsih (ed.); 3rd ed.). EGC.

Hawari. (2009). Pendekatan Holistik Pada Gangguan Jiwa Skizofrenia. Egc.

Keliat, B. A., Akemat, Helena, N., \& Nurhaeni, N. (2011). Proses Keperawatan Kesehatan Jiwa. In EGC, Jakarta.

Stuart, Gail W, \& Sundeen. (2012). Buku Saku Keperawatan Jiwa. In Local Responses to the English Reformation.

Stuart, Gail Wiscarz. (2013). Principle and practice of Psychiatric nursing, 10th Edition. In St. Louis.

Suharsimi, A. (2006). Prosedur penelitian suatu pendekatan praktik. Jakarta: Rineka Cipta.

Suryaningsih, V., Winarso, M., \& Warsini, S. (2007). Pengaruh Terapi Aktivitas Kelompok Stimulasi Persepsi Halusinasi Terhadap Frekuensi Halusinasi. In Jurnal Ilmu Keperawatan UGM (Vol. 2, Issue 1, p. 100371).

Townsend, M. (2005). Essential of Psychiatric Mental health Nursing. In F.A. Davis Company. 